\title{
THE RIGHT TO A PROSPEROUS LIFE BORN AND INNER: \\ GENDER CHANGE PERSPECTIVE
}

\section{Mochamad Ade Syukur Nur ALAM (iD) 1*}

Abdul Rachmad BUDIONO (iD ${ }^{2}$

\author{
Abdul MADJID (iD $^{3}$ \\ Istislam (iD) \\ 1 Brawijaya University, Faculty of Law, hukumlawrecht@gmail.com *Correspondent Author. \\ ${ }^{2}$ Brawijaya University, Faculty of Law, rachmad.budiono@ub.ac.id \\ ${ }^{3}$ Brawijaya University, Faculty of Law, abdul.madjid@ub.ac.id \\ ${ }^{4}$ Brawijaya University, Faculty of Law, istislam@ub.ac.id
}

\author{
Article history: \\ Submission 26 February 2021 \\ Revision 26 May 2021 \\ Accepted 14 July 2021 \\ Available online 31 August 2021

\section{Keywords:} \\ Gender Change, \\ Human Right, \\ Right to a prosperous life born and inner, \\ Justice Perspective.
}

DOI:

https://doi.org/10.32936/pssj.v5i2.243

\begin{abstract}
A b s t r a c t
Gender change is the right of every citizen, but this invites pros and cons in society. Although the 1945 Constitution of the Republic of Indonesia has regulated human rights, there is no specific mention of human rights related to sex change. This study aims to determine, examine, and analyze the meaning of "the right to a prosperous life born and inner" as referred to in Article $28 \mathrm{H}$ paragraph (1) of the 1945 Constitution of the Republic of Indonesia and Article 9 paragraph (2) of the Human Rights Law, from the perspective of justice related to sex change in Indonesia. Indonesia. This research is a normative legal research with philosophical, legislative, conceptual, case and comparative approaches. The analysis technique uses descriptive, comparative, evaluative and argumentative techniques. The results of the study indicate that the meaning of the right to live in physical and spiritual prosperity in the perspective of gender change is the right to conditions in which an individual with a gender disorder gets health care, safety, and is free from all kinds of disturbances and suffering in order to develop physically, mentally, and physically. spiritual, and social so that the individual realizes his own abilities, can cope with pressure, can work productively, and is able to contribute to himself, his family, community, and society in his environment.
\end{abstract}

\section{Introduction}

People's lives in Indonesia cannot be separated from the influence of global community life in the midst of rapid advances in technology and information that continues to roll. Ikrar (2010) states that globalization will have an impact on all aspects of life. This includes aspects of health services. One form of health care is plastic surgery. Plastic surgery to change gender from male to female or from female to male. Sex change that is carried out through a medical process or commonly called sex change surgery, invites pros and cons in the community.

The 1945 Constitution of the Republic of Indonesia has provided a wider scope for human rights. In Chapter XA the provisions of
Article $28 \mathrm{~A}$ to Article $28 \mathrm{~J}$ specifically regulate human rights. However, in these articles, there is no article that specifically mentions human rights related to sex change. Therefore, a more specific and specific elaboration of legal norms is needed.

The provisions of Article 28H paragraph (1) of the 1945 Constitution of the Republic of Indonesia are a mandate as well as the embodiment of the objectives of the administration of the Republic of Indonesia as contained in the Fourth Alenia of the Preamble to the 1945 Constitution of the Republic of Indonesia. In line with the provisions in Article $28 \mathrm{H}$ paragraph (1) of the 1945 Constitution of the Republic of Indonesia, Law No. Law Number 39 of 1999 concerning Human Rights in Article 9 
paragraph (2) states that "Everyone has the right to live in peace, security, peace, happiness, physical and spiritual prosperity".

However, the Human Rights Law also does not explain the meaning of the intended physical and mental welfare rights. Because in the Explanation section of Article by Article it is stated "Quite clear". Whereas the clarity of the meaning of the right to live in physical and spiritual prosperity is needed as a measure of 2 (two) prepositions in the formulation of the provisions of Article $28 \mathrm{H}$ of the 1945 Constitution of the Republic of Indonesia and Article 9 paragraph (2) of the Human Rights Law. In this Law on Human Rights, there is also no 1 (one) provision that mentions sex change. Even the word "sex" is only found in 1 (one) provision, namely in Article 1 number 3 which regulates the definition of "Discrimination" (Faradz, 2011).

The concept of the right to live in prosperity based on the 1945 Constitution of the Republic of Indonesia and the Human Rights Law includes two aspects, namely physical prosperity and inner prosperity, both of which cannot be separated and must be fulfilled. The right to live in prosperity is the right of every citizen in Indonesia. Including for people with Ambiguous Genitalia and Transgender people who have the right to live in physical and spiritual prosperity as Indonesian citizens. The group of people with Ambiguous Genitalia is a group that is really physically sick (genital) which affects their psychological condition.

There is often confusion between people with Ambiguous Genitalia and transsexuals or transgender people in society. Widhiatmoko and Suyanto (2013) state that transsexual is a psychological disorder, the shape of the genitals in transsexual sufferers is very clear, male or female, but the feelings they have are not in accordance with/opposite their gender so that they act and behave according to their feelings, even some of them try to change their anatomical shape (change gender) to suit their feelings and desires.

The issuance of the current health law has become a new chapter for plastic and reconstructive surgery, which strictly prohibits plastic and reconstructive surgery aimed at changing identity (gender), either from male to female or vice versa. In relation to plastic surgery and reconstruction, there are provisions in Article 69 paragraph (2) of Law Number 36 Year 2009 concerning Health.

On the other hand, Law Number 23 of 2006 concerning Population Administration has provided space for everyone to submit an application to change their resident identity in this case for a change in gender as long as it has received a determination by the district court as stipulated in the provisions of Article 56 paragraph (1) Population Administration Law.

Referring to the 2 (two) statutory provisions mentioned above, the proposition built by the researcher, that a person can make a sex change through the initial step by submitting a sex change application addressed to the district court. Furthermore, in the event that the district court decides to grant the request for a gender change that is requested by a person with Ambiguous Genitalia or Transgender, then the next process is a gender change in the identity of the Transgender or a person with Ambiguous Genitalia by the Civil Registration Officer.

The process of changing gender identity by the Civil Registration Officer is carried out through a mechanism for recording other important events as regulated in Article 56 paragraph (1) of the Population Administration Law. After changing gender identity, then Transgender or someone with Ambiguous Genitalia can perform plastic and reconstructive surgery without being deemed to have violated the provisions of Article 69 paragraph (2) of the Health Law.

In the event that the district court in its stipulation turns out to have rejected the request for a sex change from a transgender or a person with ambiguous genitalia, the identity change process through the mechanism for recording important events cannot be carried out. This has resulted in sex change through plastic or reconstructive surgery being forbidden to do. In essence, plastic and reconstructive surgery solely with the aim of changing gender from male to female or vice versa can only be carried out, after the decision of the district court followed by the recording of other important events by the Civil Registration Officer.

Legal facts show the need for the existence of legal norms that function as a tool for judges in examining, adjudicating, and deciding on requests for sex change, so that the decisions issued are expected to be decisions that reflect justice, benefit, and legal certainty for Trans genders or someone with Ambiguous Genitalia as the applicant. gender change (Fanani, 2014). On the other hand, as stipulated in Article 10 paragraph (1) of Law Number 48 of 2009 concerning Judicial Power, it is stated that the court cannot refuse to try on the pretext of the absence of legal rules governing.

Even if there is no legal norm that regulates it, the judge is still considered to know the law for what he is examining (adagium: iura novit curia). Therefore, the judge must seek the law for what he is examining. The Panel of Judges in their legal considerations, their decision should have a "framing" of justice for Ambiguous Genitalia and transgender sufferers for the sake of Justice Based 
on the One Godhead. Because it means that judges must make justice above all others, including legal certainty. Especially because sex change does not yet have legal certainty in Indonesia. Based on the legal issues above, this study will discuss more deeply the meaning of "the right to a prosperous life born an inner" as referred to in Article 28H paragraph (1) of the 1945 Constitution of the Republic of Indonesia and Article 9 paragraph (2) of the Human Rights Law, from the perspective of related justice gender change in Indonesia.

\section{Research Method}

This type of research is a legal research, which is a research conducted through a way of reviewing the rules and laws that apply to answer the legal problems studied (Efendi dan Ibrahim, 2016). The research approach uses a philosophical approach, a statutory approach, an analytical approach, a conceptual approach, a case approach and a comparative approach. The sources of legal materials used consist of primary legal materials, secondary legal materials, tertiary legal materials or non-legal materials. Primary legal materials consist of statutory regulations; secondary legal materials consist of all publications on law that are not official documents. Tertiary legal materials consist of encyclopedias and legal dictionaries. Legal material analysis techniques are carried out through several stages, namely: descriptive techniques, comparative techniques, evaluative techniques and finally argumentative techniques (Diantha, 2015).

\section{Results and Discussion}

\subsection{The Urgency of the Meaning of the Right to a Prosperous Life Born an Inner}

Based on the provisions of Article 28H paragraph (1) of the 1945 Constitution of the Republic of Indonesia and Article 9 paragraph (2) of the Human Rights Law, the state guarantees everyone without exception having the right to live in prosperity, both physically and mentally. The principle of equality and without discrimination is also documented in the constitution, as stipulated in Article 28D paragraph (1) of the 1945 Constitution of the Republic of Indonesia which emphasizes that the state provides fair recognition, guarantees, protection and legal certainty and equal treatment for everyone before the law. Therefore, this human right of course also applies to groups that are often marginalized in society such as transsexuals and hermaphrodites. As stated by Gunawan Setiardja, that human rights mean rights inherent in humans based on their nature, so the rights that humans have as humans, therefore we must not exclude certain groups (Setiarja, 1993).

If we compare the scope of human rights between the provisions in Article $28 \mathrm{H}$ paragraph (1) of the 1945 Constitution of the
Republic of Indonesia and the provisions in Article 9 paragraph (2) of the Human Rights Law, then the scope of human rights in the provisions of Article $28 \mathrm{H}$ paragraph (1) of the 1945 Constitution of the Republic of Indonesia feels wider than with the provisions of Article 9 paragraph (2) of the Human Rights Law. This is because Article 28H paragraph (1) of the 1945 Constitution of the Republic of Indonesia not only regulates the right to live in physical and spiritual prosperity as is Article 9 paragraph (2) of the Human Rights Law, but also the human right for everyone to live, to have a good environment. and healthy, as well as the right to obtain health services.

If we diversify the provisions of Article $28 \mathrm{H}$ paragraph (1) of the 1945 Constitution of the Republic of Indonesia, then there are 4 (four) human rights which are protected and guaranteed by the state for everyone. Meanwhile, the provisions of Article 9 paragraph (2) of the Human Rights Law bring a single issue, namely the right to a peaceful, safe, peaceful, happy, physically and mentally prosperous life. Carrying the same legal issue regarding the human right to live in physical and spiritual prosperity, but in both laws they do not provide clear and definite limits and measurements as a prescription that is "grounded" as well as reflects the principle of clarity of formulation.

The ambiguity of the meaning of the right to live in physical and spiritual prosperity is due to the fact that neither in the 1945 Constitution of the Republic of Indonesia (amended) nor in Article 9 paragraph (2) of the Human Rights Law, no explanation is found regarding the meaning of the right to live in physical and spiritual prosperity itself, including in the explanation section. Article by article. Likewise, in the Social Welfare Law and its implementing regulations, there is not even a mention of the phrase "prosperous life born an inner". So that the two articles do not cause multiple interpretations or have a clear formulation.

The search for the meaning of the right to live in physical and spiritual prosperity becomes important as an effort to present the dimension of legal philosophy in the case of sex change in Indonesia, along with the reality of several requests for sex change on the pretext of feeling uncomfortable with the gender of the applicant. This gender discomfort occurred in 2 (two) subjects, namely the transsexual group who medically "needs" a sex change and the hermaphrodite group which in this context "needs" the perfection of their own sex. This is reflected in the court's decision that has decided on the application of the two legal subjects.

The following are some of the decisions made by the District Court on requests for sex change in Indonesia, including: 
Number 517/Pdt.P/2012/PN. YK, with the name of the applicant Thio Wi Kun;

b. Determination of the Semarang District Court Number 518/Pdt.P/2013/PN.Ung, with the name of the applicant Supriyanti;

c. Determination of the Klaten District Court Number 77/ Pdt.P/2014/PN Kln, with the name of the applicant Sally Novi Marcelina;

d. Determination of the Boyolali District Court Number 54/Pdt.P/2015/PN Byl, with the names of the applicants Sugiman and Suciati/Nuri Winarti; and

e. Determination of the Surakarta District Court Number 87/Pdt P/2016/PN Skt, with the name of the applicant Romandito Haryo Prabowo.

Several court decisions on requests for sex change have been decided by the courts. In some cases, the application for sex change in the district court has been preceded by sex change through plastic surgery. So that in this context the sex of the applicant has physically changed and no longer matches his identity. For example, the cases of Vivian Rubianti, Henriette Soekotjo, Thio Wi Kun, Supriyanti, and Romandito Haryo Prabowo. Of course, this makes the position of the judge more difficult to reject the application submitted by the applicant with a different gender from the identity.

While the judge must consti- tute (find legal facts), qualify (find and classify the laws and regulations relating to the subject matter), and constitutive (stipulate the law of the case) (Asnawi, 2013), but on the other hand the rule of law which regulates sex change in Indonesia cannot be used as a "qualification tool" for the panel of judges in deciding whether to grant/reject the application submitted to the court. Likewise, the influence of the principle of "ius curia novit" (Ali and Heryani, 2012) or "iura novit curia" (Spagnolo, 2011) which means "court knows the law", which means that every judge is considered to know the law of the case being examined or tried. actually requires the judge to decide on this sex change application. Therefore, judges have an obligation to explore, follow, and understand the values of justice that live in society as stipulated in the provisions of Article 5 paragraph (1) of the Law on Justice.

One of the pendulum pendulums of justice that can be used by the panel of judges in deciding the application for sex change is to find the true meaning of the right to live in physical and spiritual prosperity for everyone as mandated by Article $28 \mathrm{H}$ paragraph (1) of the 1945 Constitution of the Republic of Indonesia and Article 9 paragraph (2) Human Rights Act. Considering that as legal subjects, this transsexual and hermaphrodite condition is highly correlated with these 2 (two) aspects, namely the outer and inner aspects.

The correlation between physical and spiritual aspects with transsexuals is illustrated in court decisions and the documented reality of transsexuals below:

a. Surakarta District Court Decision Number $87 / \mathrm{Pdt}$ P/2016/PN Skt, the applicant on behalf of ROMANDITO HARYO PRABOWO, in his application letter dated March 31, 2016 he stated that since childhood the Petitioner had felt different, the Petitioner felt as a woman, even though physically and in some documents the Petitioner is stated as a man;

b. The decision of the Klaten IB District Court with the determination Number 77/Pdt.P/2014/PN Kln, the applicant on behalf of SALLY NOVI MARCELINA, in his application letter dated December 6, 2010, he stated that the applicant in his daily life was more comfortable and chose to have a male gender. males, although the number of chromosomes tends to be dominant in females, because the applicant's physical and psychological/mental conditions are more dominant in males.

c. Physically a man, but spiritually a woman, for example the case of Dorce, Vivian Rubianti (Nadia, 2003); and

d. Physically women, but spiritually men, for example the case of Dra. Rio Agusto Vishnu Murti.

While in the hermaphrodite group, this outer and inner aspect is illustrated in the following cases:

a. The decision of the Semarang District Court in Ungaran with the determination Number 518/Pdt.P/2013/PN.Ung., the applicant on behalf of SUPRIYANTI, in his application letter dated June 18, 2013 he stated that the child after getting bigger and growing showed good signs physically. physically and clinically tend to be a male figure;

b. Boyolali District Court Decision Number 54/Pdt.P/2015/PN Byl, the petitioners on behalf of SUGIMAN and SUCIATI, in their application letter dated 15 October 2015 stated that after the age of 18 the Petitioners' children changed gender to become male. men according to the results of SEMEN ANALYSIS from the FERTILITY CLINIC "SEKAR MOEWARDI" and a Certificate of Examination Results from the REGIONAL GENERAL HOSPITAL Dr. MOEWARDI issued by a.n. Director of RSUD Dr. MOEWARDI CENTRAL JAVA PROVINCE Plh. Deputy Director of Services (Dr.dr. SUHARTO WIJANARKO, Sp. U) who explained that NURI WIYARTI is male;

c. The case of Rogayah-not her real name. A hermaphrodite from Bandung, West Java (Tempo, 1985). 
Rogayah since she was a toddler has been treated as a woman. When he entered the age of puberty, he seemed to have female symptoms in him, although not complete. For example, he experienced his chest also appear, but not perfect. Changes occurred when Rogayah was about 17 years old, where he felt like a man. He had a wet dream and released sperm. More than that, Rogayah also has a girlfriend. However, from the results of the doctor's examination, it turned out that Rogayah's penis was considered very small, with a diameter of 0.5 centimeters and a length of 2 centimeters. A strong reason that Rogayah is a man is the result of an ultrasound examination which states that there are no female organs in Rogayah's body (Koewinarno, 2004).

Several court decisions above have illustrated how the correlation between the outer and inner aspects with transsexual and hermaphrodite conditions as legal subjects in court is very strong. The outer and inner aspects themselves cannot be separated from the existence of natural human existence. Even a French philosopher, Rene Descrates in his phenomenal phrase stated "cogito ergo sum" which means because I think I exist. This indicates that mere physical existence is not a complete human presence. Although not exactly the same in the use of terminology and the number of divisions, the approach to thinking about the position of humans in the view of natural law is a milestone in the history of the same thought towards the existence of this human dichotomous.

\subsection{Meaning of a Prosperous Life Born and Inner}

The issue of justice as the main theme in perennial (eternal) law, is in line with the long history of thinking about the definition of justice itself, even starting in ancient Greece (Manullang, 2006). However, at least the justice proposed by John Rawls through 2 (two) mainstream concepts of justice, namely ethical justice and institutional justice, can be accepted as proportional justice for applicants for sex change. Ethical justice which views justice that prioritizes rights rather than the benefits of justice itself, while institutional justice emphasizes prioritizing benefits over rights (Asnawi, 2013).

The term "outward and inner" itself in people's lives in Indonesia is sometimes placed parallel to several other terms (which are considered) similar, for example: physical-spiritual, physicalspiritual, physical-psychic, and material-spiritual, which are symbol of the unity between the body and spirit of a human being. This is not entirely to blame if viewed from the grammatical meaning.

Some experts include the provisions of Article 28H paragraph (1) of the 1945 Constitution of the Republic of Indonesia in the social welfare cluster, one of which is Kurnia (2015). In his writings, stating that according to its functional nature, the concept of social welfare rights by Titon Slamet Kurnia is used as a synonym for economic, social and cultural rights.

Meanwhile, in the Social Welfare Law, the definition of Social Welfare is the condition of meeting the material, spiritual and social needs of citizens in order to live decently and be able to develop themselves, so that they can carry out their social functions (see Article 1 point 1). The targets of social welfare based on the Social Welfare Law include: individuals, families, groups, and/or communities who experience poverty, neglect, disability, remoteness, social disability and behavioral deviations, disasters, and/or acts of violence, exploitation and discrimination (see Article 5).

The provisions of Article 28H paragraph (1) of the 1945 Constitution of the Republic of Indonesia are contained in Chapter XA** with the chapter title "HUMAN RIGHTS". The search for the meaning of the phrase "Every citizen has the right to live in physical and spiritual prosperity" as mandated in Article 28H paragraph (1) of the 1945 Constitution of the Republic of Indonesia is continued in the Human Rights Law. History records that this Law was proposed by the Government to the House of Representatives of the Republic of Indonesia during the Fourth Session of the 1998-1999 Session Year through the Letter of the President of the Republic of Indonesia Number R.09/PU/1999, dated February 8, 1999, regarding Submission of the Draft Law. on Human Rights and the National Human Rights Commission (Secretariat General of the House of Representatives of the Republic of Indonesia, 2001). The Human Rights Law as a follow-up to the mandate of the MPR Decree Number XVII/MPR/1998 on Human Rights was proposed by the Government in conjunction with the Law on the National Human Rights Commission.

In the Government's statement before the House of Representatives, Prof. Dr. Muladi, SH, said that the main reason for the proposed draft of the Human Rights Law, apart from following up on the mandate of the MPR Decree Number XVII/MPR/1998 on Human Rights, the main thing was to answer the implementation of respect, protection, and enforcement of human rights in Indonesia which is still far away. from satisfying. In the Human Rights Law, the phrase "prosperous born and inner" is formulated in Article 9 paragraph (2), which states in full that "Everyone has the right to live in peace, security, peace, happiness, physical and spiritual prosperity". The phrase "prosperous physically and mentally" has been proposed by the Government since the beginning of the discussion of Article 9 paragraph (2) of the Human Rights Law. However, in the initial 
formulation of Article 9 paragraph (2) of the Human Rights Law, there were 2 (two) additional words, namely "safe" and "peaceful" during the discussion. In the initial draft of the Human Rights Bill when the formulation of the provisions of Article 9 paragraph (2) has not yet been ratified, it reads: "Everyone has the right to live in peace, happiness, physical and spiritual prosperity". After going through a long discussion, the Chairman of the DPR H. Harmoko through the Decree of the House of Representatives Number 6/DPR-RI/I/1999-2000 dated September 8, 1999, approved the draft Law on Human Rights Law.

Referring to the history of the formulation of physical and spiritual prosperity in Article 28H paragraph (1) of the 1945 Constitution of the Republic of Indonesia and Article 9 paragraph (2) of the Human Rights Law, the birth of human rights in the 1945 Constitution of the Republic of Indonesia, cannot be separated from the background of the birth of several international legal instruments which regulates human rights, especially the Universal Declaration of Human Rights. Firdaus (2004) stated that this fact prompted the Habibie government to ratify various international human rights instruments and issue a Human Rights Law. Meanwhile, on the other hand, the MPR did not want to miss out on amending the 1945 Constitution to incorporate human rights norms into its body. So that in the end it caused irregularities in the history of the formulation of the 1945 Constitution of the Republic of Indonesia, where the Human Rights Law existed first and became the source of the material for the content of human rights in the 1945 Constitution of the Republic of Indonesia.

Referring to the search on the history of the formulation of the phrase "prosperous born and inner" above, it can be described as follows:

Figure 1. Schematic of the History of the Phrase "Prosperous Born and Inner"

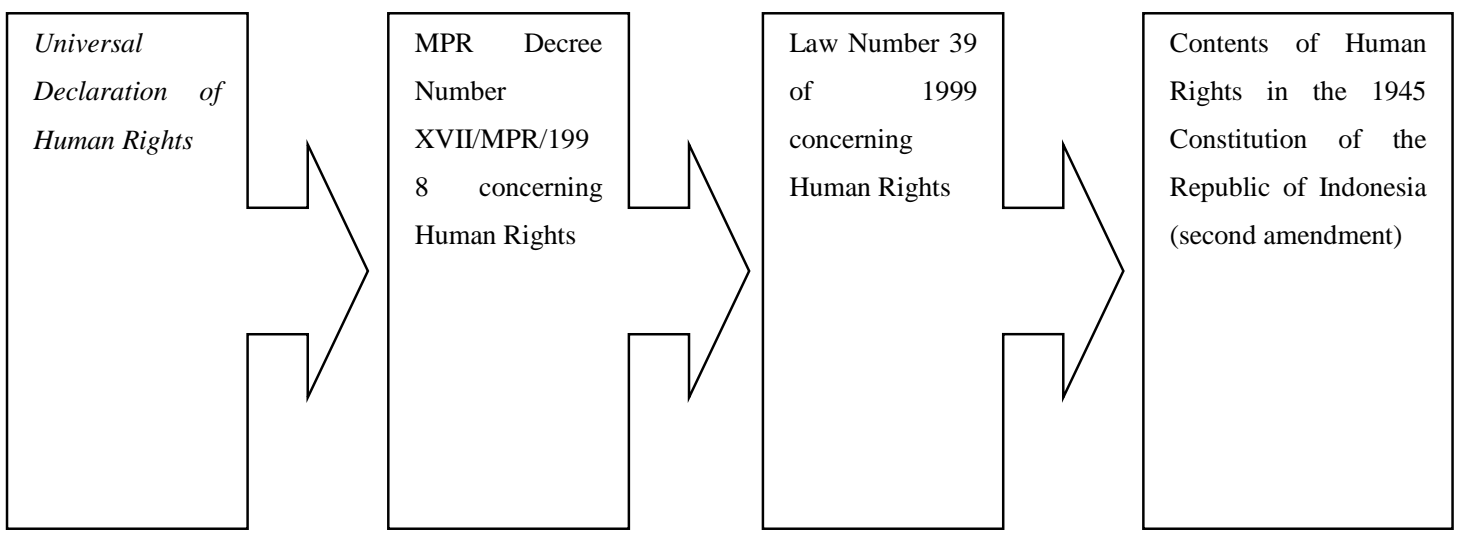

The differences in the formulation of the regulation of welfare rights among the four legal products above are as follows:

Table 1. Different formulations regarding the regulation of welfare rights

\begin{tabular}{|c|c|c|c|}
\hline $\begin{array}{l}\text { Universal Declaration of } \\
\text { Human Rights on } 10 \\
\text { December } 1948\end{array}$ & $\begin{array}{l}\text { MPR Decree Number } \\
\text { XVII/MPR/1998 }\end{array}$ & Human Right Law & $\begin{array}{l}1945 \text { Constitution of the } \\
\text { Republic of Indonesia }\end{array}$ \\
\hline $\begin{array}{l}\text { Article } 25 \text { Paragraph 1: } \\
\text { Everyone has the right to a } \\
\text { standard of living adequate } \\
\text { for the health and well-being } \\
\text { of himself and of his family, } \\
\text { including food, clothing, } \\
\text { housing and medical care } \\
\text { and necessary social } \\
\text { services, and the right to } \\
\text { security in the event of } \\
\text { unemployment, sickness, } \\
\text { disability, widowhood, old }\end{array}$ & $\begin{array}{l}\text { Pasal 27: } \\
\text { Everyone has the right to } \\
\text { live in physical and spiritual } \\
\text { prosperity. } \\
\text { Article 28: } \\
\text { Everyone has the right to a } \\
\text { good and healthy } \\
\text { environment. } \\
\text { Article 29: }\end{array}$ & $\begin{array}{l}\text { Article } 9 \text { paragraph (2): } \\
\text { Everyone has the right to } \\
\text { live peacefully, safely, } \\
\text { peacefully, happily, } \\
\text { physically and mentally. }\end{array}$ & $\begin{array}{l}\text { Article } 28 \mathrm{H} \text { paragraph (1): } \\
\text { Everyone has the right to } \\
\text { live in physical and spiritual } \\
\text { prosperity, } \\
\text { live, and get a living } \\
\text { environment } \\
\text { good and healthy and have } \\
\text { the right to obtain health } \\
\text { services.** }\end{array}$ \\
\hline
\end{tabular}




\begin{tabular}{|l|l|l|l|}
\hline $\begin{array}{l}\text { Universal Declaration of } \\
\text { Human Rights on 10 } \\
\text { December 1948 }\end{array}$ & $\begin{array}{l}\text { MPR Decree Number } \\
\text { XVII/MPR/1998 }\end{array}$ & Human Right Law & $\begin{array}{l}\text { 1945 Constitution of the } \\
\text { Republic of Indonesia }\end{array}$ \\
\hline $\begin{array}{l}\text { age or other lack of } \\
\text { livelihood in circumstances } \\
\text { beyond his control. }\end{array}$ & $\begin{array}{l}\text { Everyone has the right to } \\
\text { live and have a decent life. }\end{array}$ & & \\
\hline
\end{tabular}

From the history of the above arrangement, it shows that the issue of welfare as part of human rights in the formulation of the Universal Declaration of Human Rights on 10 December 1948 does not separate welfare into 2 (parts) namely physical prosperity and inner prosperity. The phrase "prosperous physically and mentally" in Indonesian law was first mentioned in Article 27 of the MPR Decree No. XVII/MPR/1998 on Human Rights, which states that "Everyone has the right to live in physical and spiritual prosperity." Then the mention is continued in Article 9 paragraph (2) of the Human Rights Law and Article 28H paragraph (1) of the 1945 Constitution of the Republic of Indonesia.

The search for the meaning of this phrase prospering physically and mentally is getting more complex, because both in MPR Decree No. XVII/MPR/1998 concerning Human Rights, the Human Rights Law and the 1945 Constitution of the Republic of Indonesia did not find an explanation for the provisions regarding this matter. Regarding the explanation of the 1945 Constitution of the Republic of Indonesia, actually before the amendment was made, the 1945 Constitution had an explanation section for explanation.

However, when the amendment was made, the explanation section was shifted to the torso as agreed by the People's Consultative Assembly which stated that:

a. First, it does not change the Preamble to the 1945 Constitution. The Preamble to the 1945 Constitution is preserved because it contains a philosophical and normative basis that underlies all articles in the 1945 Constitution. In addition, the Preamble to the 1945 Constitution contains the stats on the establishment of the state, the goals of the state, and the basis of the state.

b. Second, maintaining the Unitary State of the Republic of Indonesia (NKRI). The agreement to defend the Unitary State of the Republic of Indonesia is based on the consideration that the unitary state is the form that has been established since the beginning of the founding of the Indonesian state. The unitary state is also considered the most appropriate to accommodate the idea of unity of a pluralistic nation.

c. Third, reinforce the presidential system of government. The presidential system of government is considered more suitable to be applied in Indonesia. Because, when
Indonesia implemented a parliamentary system of government, the practice of administering state life was never stable. In addition, other considerations are based on the choice of the founders of the Indonesian state who established a democracy with a parliamentary system of government.

d. Fourth, negate the explanation of the 1945 Constitution by elevating normative matters into articles. The addition of articles of the 1945 Constitution by itself has changed the Elucidation of the 1945 Constitution and the explanation is deemed unnecessary.

e. Fifth, make changes by means of an addendum. Amendments by means of an addendum were chosen to maintain the authenticity of the 1945 Constitution. Thus, the original text of the 1945 Constitution and its explanation as contained in the State Gazette Number 75 of 1959 as a result of the Presidential Decree of July 51959 were attached to the text of the amendments to the 1945 Constitution. The MPR faction also agreed that the Indonesian state adheres to a system of separation of powers with a system of checks and balances.

In the perspective of Pancasila essentialia, Soekowati (1977) states that Pancasila contains a belief that the dynamics that grow from the totality of all physical and spiritual forces, from the totality of all material and spiritual forces, are the dynamics that determine the growth and development of society, the collapse and development of history and the rise of society. fall of human civilization. He further said that our ancestors hundreds of years ago had taught their children and grandchildren that humans have rights and obligations to themselves, to their families, to the state, and to God. That is why for the Indonesian people, social happiness is when an intimate harmony has been achieved between the individual and his "group" and between his "group" and the cosmos.

The right to live in physical and spiritual prosperity which is part of the human rights of every Indonesian citizen as mandated in Article $28 \mathrm{H}$ paragraph (1) of the 1945 Constitution of the Republic of Indonesia. (2) The Human Rights Law which states that "Everyone has the right to live in peace, security, peace, happiness, physical and spiritual prosperity". Basically, the meaning of the right to a prosperous life has not been found in a clear measure. As stated in the Explanation section of Article by Article of the Human Rights Law against the provisions of Article 9 paragraph (2) it is stated "Quite clear". 


\section{Conclusions}

Human rights to live in physical and spiritual prosperity in accordance with the provisions of Article $28 \mathrm{H}$ paragraph (1) of the 1945 Constitution of the Republic of Indonesia and Article 9 paragraph (2) of the Human Rights Law must be interpreted broadly and not limitedly. Because in measuring it, it is not enough to use indicators of economic welfare alone, or aspects of health, education, security, social, and other aspects partially, but are holistic and individualistic. This holism also means not limited to aspects of life, but its existence which is both intrinsic and extrinsic for an individual. This also means that the overall dose of physical and spiritual prosperity for one individual will differ from one individual to another. For example, between humans with normal hormones and chromosomes compared to humans with abnormal hormones and chromosomes, there will be differences in understanding themselves and their surroundings, even though physically there seems to be no difference.

So to measure the physical and spiritual prosperity of an individual is not appropriate if only measured from the economic side without paying attention to other aspects of life. Because every aspect of life is interrelated with one another which converges to form conclusions about the perception of inner and outer prosperity in an individual. For example, in the health aspect, the KBBI equates mental welfare with mental health. Meanwhile, if we refer to the Mental Health Law, it describes mental health as a condition in which an individual can develop physically, mentally, spiritually, and socially so that the individual is aware of his own abilities, can cope with pressure, can work productively, and is able to contribute to his community. This is highly correlated with the conditions experienced by transgender and Ambiguous Genitalia sufferers who experience psychological stress due to disturbances to their gender. In line with Dwi Prasetyo's research, someone who changes his gender must continue to struggle to carry out the negotiation process against the surrounding norms so as to produce more open gender performativity and no violence. The theory of gender performativity shows that gender occurs because of the process of materialization and construction. A person who changes his gender is a social reality through language, gestures, and all social markers that are shown.

So that the meaning of the right to live in physical and spiritual prosperity in the perspective of gender change is the right to conditions in which an individual with a gender disorder gets health, safety and free services from all kinds of disturbances and suffering in order to develop physically, mentally, spiritually, and physically. so that the individual realizes his own abilities, can cope with pressure, can work productively, and is able to contribute to himself, his family, community, and society in his environment.

Based on this conclusion, the People's Consultative Assembly as the state institution with the power to amend the 1945 Constitution of the Republic of Indonesia, to amend the provisions of Article $28 \mathrm{H}$ paragraph (1) of the NRI Constitution by placing the right to live in physical and spiritual prosperity as a large group that is meta-norm and does not align with other things. which is specific and concrete, and To the President and DPR and DPD as the holder of the power to amend the Law, to amend the provisions of Article 69 paragraph (2) of the Health Law which regulates the exclusion of plastic surgery for the purpose of changing identity with the requirement of a court order and adding 1 one) new paragraph which aims to provide legal norms for judges to grant/reject requests for sex change.

\section{References}

1. Ali, A. \& Heryani, W. (2012). Asas-asas Hukum Pembuktian Perdata. Jakarta, Kencana.

2. Asnawi, M.N. (2013). Hermeneutika Putusan Hakim. Yogyakarta, UII Press.

3. Diantha, I M. P. (2015). Metodologi Penelitian Hukum Normatif dalam Justifikasi Teori Hukum. Denpasar, Kencana Prenadamedia Group.

4. Efendi, J. and Ibrahim, J. (2016). Metode Penelitian Hukum Normatif dan Empiris. Depok, Prenadamedia Group.

5. Fanani, A.Z (2014). Berfilsafat dalam Putusan Hakim (Teori dan Praktik). Malang, CV Mandar Maju.

6. Faradz, S.M.H. (2011), Kelamin Ganda, Penyakit atau Penyimpangan Gender? Available at http://pustaka-juned.blogspot.com/2012/02/kelaminganda-penyakit-atau.html accessed on 15 July 2018 at 21.01 WIB

7. Firdaus. (2004). Hak Asasi Manusia (Hakekat, Konsep dan Implikasinya dalam Perspektif Hukum dan Masyarakat), edited by Muladi, Semarang, Refika Aditama.

8. Ikrar, T. (2010), Kedokteran Indonesia dan Globalisasi Kesehatan, Available at https://news.detik.com/opini/1335557/kedokteranindonesia-dan-globalisasi-kesehatan- accessed on 11 October 2017 at 21.17 WIB

9. Koeswinarno. (2004). Hidup Sebagai Waria. Yogyakarta, LkiS.

10. Kurnia, T.S. (2015). Interpretasi Hak-hak Asasi Manusia oleh Mahkamah Konstitusi Republik 
Indonesia the Jimly Court 2003-2008. Salatiga, CV.

Mandar Maju.

11. Manullang, E.F.M. (2016) Menggapai Hukum Berkeadilan Tinjauan Hukum Kodrat dan Antinomi Nilai. Jakarta, Penerbit Buku Kompas.

12. Nadia, Z. (2003). Waria Laknat atau Kodrat. Yogyakarta, Pustaka Marwa.

13. Prasetyo, D. (2019). Fluiditas Gender, Studi Trans Laki-Laki Indonesia. Surabaya, Universitas Airlangga.

14. Soekaowati, S. (1977). Pancasila dan Hak-hak Azasi Manusia. Jakarta, MUS KARYA Offset.

15. Setiarja, G. (1993). Hak-hak Asasi Manusia Berdasarkan Ideologi Pancasila. Semarang, Kanisius.

16. Spagnolo, L. (2011). Iura novit curia and the CISG: resolution of the faux procedural black hole. In I. Schwenzer, \& L. Spagnolo (Eds.), Towards Uniformity: the 2nd Annual MAA Schlechtriem CISG Conference (1st ed., pp. 181 - 221). Eleven International Publishing. Available at https://www.researchgate.net/publication/256018337 Iura Novit Curia and the CISG Resolution of $\mathrm{t}$ he Faux Procedural Black Hole/link/57b5815e08a ede8a665b425f/download

17. Widhiatmoko, B. and Suyanto, E. (2013). Legalitas Perubahan Jenis Kelamin pada Penderita Ambiguous Genetalia di Indonesia. Journal of Indonesian Forensic Medicine, 15(1), 12-22. Available at http://journal.unair.ac.id/filerPDF/ikfml5427baf863f $\underline{\text { ull.pdf }}$

\section{Law and Regulation}

18. Indonesia, The 1945 Constitution of the Republic of Indonesia, Available at https://www.mkri.id/public/content/infoumum/regula tion/pdf/UUD45\%20ASLI.pdf

19. Indonesia, Law Number 1 of 1974 concerning Marriage, Available at https://ngada.org/uu1$\underline{1974 . h t m}$

20. Indonesia, Law Number 39 of 1999 concerning Human Rights, Available at https://www.komnasham.go.id/files/1475231474-uunomor-39-tahun-1999-tentang-\%24H9FVDS.pdf

21. Indonesia, Law Number 23 of 2006 concerning Population Administration, Available at https://www.dpr.go.id/dokjdih/document/uu/UU_200 6 23.pdf

22. Indonesia, Law Number 11 of 2009 concerning Social Welfare. Available at
https://luk.staff.ugm.ac.id/atur/sehat/UU-11-

2009KesejahteraanSosial.pdf

23. Indonesia, Law Number 36 Year 2009 concerning Health, Available at https://rskgm.ui.ac.id/wpcontent/uploads/2021/03/07.-Nomor-36-Tahun-2009Tentang-Kesehatan.pdf

24. Indonesia, Law Number 48 of 2009 concerning Judicial Power, Available at https://www.dpr.go.id/dokjdih/document/uu/UU 200 9 48.pdf 